\title{
Penyediaan Infrastruktur dan Environmental Justice: Dampak Keberadaan Tempat Pembuangan Akhir Sampah bagi Masyarakat Sekitar
}

\author{
Sri Maryati ${ }^{1}$ \\ ${ }^{1}$ Staf Pengajar Prodi Perencanaan Wilayah dan Kota, SAPPK ITB \\ e-mail: smaryati@pl.itb.ac.id
}

\begin{abstract}
Abstrak
Dalam konteks environmental justice (EJ) paper ini mengeksplorasi dampak penyediaan infrastruktur persampahan terhadap masyarakat sekitar. Infrastruktur persampahan yang bermanfaat bagi kelompok masyarakat tertentu telah menimbulkan dampak negatif bagi kelompok masyarakat lainnya karena tidak dikelola dengan baik. Metoda penelitian yang digunakan adalah metoda analisis kualitatif dan kuantitatif. Penelitian ini menunjukkan bahwa pengelolaan infrastruktur persampahan yang kurang baik di masa lalu, pada saat ini masih menimbulkan berbagai dampak terhadap masyarakat. Beberapa dampak yang timbul antara lain adalah penurunan kualitas air, timbulnya bau, penurunan estetika lingkungan, dan penurunan harga lahan. Beberapa implikasi dan rekomendasi diusulkan untuk mengatasi persoalan EJ, antara lain penyediaan infrastruktur air bersih public, penyediaan buffer zone, penampungan dan pengelolaan lindi, serta pemantapan pedoman penentuan lokasi TPA yang terletak pada dua wilayah administrasi atau berbatasan dengan wilayah administrasi lain, atau TPA suatu wilayah terletak pada wilayah administrasi lain.
\end{abstract}

\begin{abstract}
In the context of environmental justice (EJ) this paper explores the impact of providing solid waste infrastructure to the communities. Solid waste infrastructure that is beneficial to certain community groups has a negative impact on other community groups because it is not managed well. The research method used is a qualitative and quantitative analysis method. This research shows that the poor management of waste infrastructure in the past, currently still causes various impacts to the community. Some of the impacts are decreasing water quality, odor, decreasing environmental aesthetics, and decreasing land prices. Some implications and recommendations are proposed to overcome the EJ problem, including the provision of public clean water infrastructure, provision of buffer zones, shelter and leachate management, and strengthening guidelines for the determination of landfill sites located in two administrative areas or bordering other administrative areas, or landfill in one region that located in another administrative area.
\end{abstract}

Kata kunci: environmental justice, infrastruktur, dampak, persampahan, tempat pembuangan akhir sampah

\section{LATAR BELAKANG}

Infrastruktur merupakan elemen fisik yang harus disediakan oleh pemerintah atau badan swasta di suatu kota atau wilayah. Tanpa adanya infrastruktur fungsi dari suatu kota atau wilayah akan terhambat. Infrastruktur persampahan merupakan salah satu infrastruktur yang harus disediakan dalam menangani sampah yang dihasilkan oleh masyarakat. Berbeda dengan infrastruktur lainnya, dalam infrastruktur persampahan dikenal adanya istilah NIMBY (not in my backyard) yang menunjukkan bahwa masyarakat cenderung menolak adanya infrastruktur persampahan yang dibangun di sekitar tempat tinggalnya. Keberadaan infrastruktur persampahan menimbulkan sejumlah dampak pada lingkungan sekitarnya, apalagi jika pengelolaan sampah tidak dilakukan secara benar.

Tahapan pengelolaan sampah meliputi pewadahan, pengumpulan, transfer dan pengangkutan, serta disposal. Pada kebanyakan kasus di Indonesia, dimana belum dilakukan 
Penyediaan Infrastruktur dan Environmental Justice:

Dampak Keberadaan Tempat Pembuangan Akhir Sampah bagi Masyarakat Sekitar

pemilahan secara baik di sumber serta terbatasnya pengelolaan yang dilakukan di sumber maupun di Tempat Penampungan Sementara (TPS) telah menimbulkan beban yang cukup besar pada tahap disposal. Disposal atau pembuangan sampah umumnya dilakukan di Tempat Pemrosesan Akhir (TPA) dalam bentuk landfill.

TPA membutuhkan lahan yang luas, apalagi bila pengelolaan sampah yang dilakukan masih menganut prinsip kumpul-angkut-buang. Beberapa kota yang umumnya mempunyai lahan yang terbatas, tidak dapat menyediakan lahan untuk TPA. Beberapa kota menggunakan lahan TPA pada wilayah administrasi lain yang berdekatan yang mampu menyediakan lahan yang cukup luas. Pemilihan lokasi TPA umumnya hanya mempertimbangkan ketersediaan lahan, kepemilikan lahan, dan harga lahan. Pedoman yang mengatur pemilihan lokasi TPA terdapat pada SNI 03-3141-1994. Namun demikian pedoman tidak mempunyai kekuatan hukum. Disamping itu, pedoman ini diterbitkan pada tahun 1994. Fakta ini menunjukkan bahwa sebelumnya pemilihan lokasi TPA belum terstandarkan.

Salah satu kota yang memiliki keterbatasan dalam penyediaan lahan TPA adalah DKI Jakarta. Lahan TPA untuk penanganan sampah dari DKI Jakarta terletak di Kota Bekasi, yaitu TPA Bantargebang. Volume sampah dari DKI Jakarta yang ditimbun di TPA Bantargebang pada tahun 2017 adalah 11.686 ton/hari (KLHK, 2019). Pengelolaan sampah pada saat ini telah mengikuti standar sanitary landfill, namun sebelumnya pengelolaan sampah di TPA Bantargebang belum mengikuti standar. Keberadaan TPA atau pada saat ini TPST Bantargebang telah menimbulkan berbagai dampak pada wilayah-wilayah yang berbatasan dengan lokasi TPA, termasuk diantaranya adalah Desa Taman Rahayu yang terletak di Kabupaten Bekasi. Dalam konteks EJ, penyediaan infrastruktur yang bermanfaat bagi sekelompok masyarakat telah menimbulkan dampak negatif bagi kelompok masyarakat lainnya. Dalam konteks ini, EJ terkait dengan keadilan distribusi. Tujuan penelitian ini adalah untuk mengeksplorasi dampak keberadaan infrastruktur persampahan bagi masyarakat sekitarnya dan mengkaitkan dampak yang terjadi dengan konsep environmental justice (EJ). Penelitian ini menggunakan kasus studi di Desa Taman Rahayu, Kabupaten Bekasi yang berbatasan langsung dengan Tempat Pengolahan Sampah Terpadu (TPST)
Bantargebang di Kota Bekasi. TPST Bantargebang merupakan tempat pengolahan akhir sampah untuk melayani penduduk DKI Jakarta. Untuk kasus TPST Bantargeang, wilayah pelayanan, lokasi TPST, dan wilayah terdampak yang akan dikaji berbeda wilayah administrasi. Beberapa pertanyaan dalam penelitian ini adalah: 1) apa saja dampak yang ditimbulkan oleh TPST Bantargebang terhadap masyarakat sekitar dan apakah telah terjadi environmental (in)justice, 2) bagaimana masyarakat mengatasi dampak-dampak terjadi, 3) bagaimana langkah yang dapat diambil oleh pemerintah dalam menciptakan distribusi manfaat yang berkeadilan.

\section{ENVIRONMENTAL JUSTICE DAN DAMPAK KEBERADAAN INFRASTRUKTUR PERSAMPAHAN BAGI MASYARAKAT SEKITAR}

\subsection{Konsep Environmental Justice}

Environmental Justice (EJ) merupakan konsep yang berhubungan erat dengan pembangunan berkelanjutan (sustainable development). Konsep ini berhubungan dengan distribusi yang berkeadilan antara biaya dan manfaat lingkungan. Konsep ini menghubungkan proteksi lingkungan dan keadilan sosial. EJ didefinisikan sebagai perlindungan non diskrimiantif terhadap paparan bahaya-bahaya lingkungan (Mitchell dan Dorling, 2003). Beberapa kelompok masyarakat merupakan kelompok yang harus dipertimbangkan dalam EJ antara lain masyarakat berpendapatan rendah, penduduk asli, dan kelompok minoritas (EPA, 2016). Kelompok masyarakat ini lebih cenderung terpapar terhadap dampak-dampak lingkungan EPA (2016) menyatakan bahwa infrastruktur dapat merupakan kontributor terhadap paparan dampak lingkungan yang lebih tinggi. Dalam konteks keberadaan TPA atau TPST yang merupakan salah satu jenis infrastruktur persampahan, lahan yang digunakan umumnya merupakan lahan dengan nilai yang rendah yang ditempati oleh penduduk asli ataupun penduduk berpendapatan rendah. Keberadaan penduduk asli atau lokal dan penduduk berpendapatan rendah di sekitar lokasi TPST menyebabkan paparan yang lebih tinggi terhadap kelompok masyarakat tersebut. Pada sisi lain kelompok tersebut memiliki keterbatasan dalam menanggulangi dampak karena keterbatasan secara ekonomi, sosial, maupun politis. Clough (2018) menegaskan bahwa dalam konteks EJ hal 
penting yang harus diperhatikan adalah siapa yang menanggung dampak.

McCauley dan Heffron (2018) menyatakan bahwa terdapat tiga jenis environmental justice, yaitu distribusi, prosedur, dan restorasi. Distribusi adalah EJ yang terkait dengan distribusi yang adil dari manfaat sosial dan ekonomi kepada masyarakat. Prosedur berarti adanya keadilan dalam pengambilan keputusan. Restorasi adalah keadilan dalam menanggulangi dampak.

EJ dapat diciptakan melalui kebijakan-kebijakan dan pengambilan keputusan yang berkeadilan. Namun demikian Jenkins (2018) menyatakan bahwa banyaknya persoalan lingkungan pada saat ini menunjukkan bahwa pengaruh EJ dalam pengambilan keputusan tidak efektif. Untuk itu beberapa pedoman yang seringkali dijadikan acuan dalam pengambilan keputusan harus dievaluasi agar dapat mengakomodasi konsep EJ.

Disamping kebijakan-kebijakan yang bersifat topdown, EJ dapat pula diciptakan secara bottom-up dalam bentuk inisiatif lokal. Salah satu inisitif lokal dalam menciptakan EJ adalah unit price dalam pengelolaan sampah (Weber dkk, 2019).

\subsection{Dampak Keberadaan TPA terhadap Masyarakat Sekitar}

Dampak keberadaan TPA tehadap masyarakat sekitar sudah lama menjadi obyek kajian beberapa penelitian. Kontaminasi air tanah dan bau merupakan dampak yang sering timbul dari TPA yang mengalami kegagalan teknis maupun persoalan manajemen (Liu dkk, 2019; Kapelewska, 2019). Dampak-dampak ini dapat berpengaruh pada kesehatan manusia.

Pencemaran air akibat TPA antara lain telah dibuktikan dalam beberapa penelitian. SanchezArias et al (2019) menyatakan bahwa TPA telah mencemari air penduduk. Penelitian yang dilakukan di Meksiko ini menunjukkan bahwa pencemaran air telah terjadi hingga radius $500 \mathrm{~m}$ dari landfill. Pencemaran yang terjadi adalah pencemaran ir permukaan dan pencemaran tanah. Air merupakan komponen penting dalam EJ. Mitchell (2019) dalam penelitian kasus pencemaran air pada masyarakat lokal Indian menyatakan bahwa air berperan dalam kesehatan masyarakat lokal Indian dan merupakan prasyarat untuk mewujudkan EJ (Mitchell, 2019).

Bau yang ditimbulkan dari landfill merupakan persoalan yang cukup mengganggu. Dengan menggunakan kasus di Cina, Cai dkk (2015) menunjukkan bahwa bau dapat dirasakan hingga rata-rata jarak $796 \mathrm{~m}$ dari lokasi TPA. Penelitian yang dilakukan oleh Cai, dkk ini menggunakan pendekatan bottom up berdasarkan persepsi responden.

Disamping dampak-dampak yang telah disebutkan, Makarenko dan Budak (2017) menyatakan bahwa sampah kering yang beterbangan juga merupakan persoalan yang ditimbulkan oleh TPA yang tidak dikelola dengan baik. Lebih lanjut Makarenko dan Budak (2017) menyatakan bahwa lokasi TPA perlu diatur dengan baik.

Banyaknya kasus pencemaran akibat TPA menunjukkan bahwa di beberapa tempat, khususnya di negara berkembang, pemilihan lokasi TPA tidak didasarkan pada kriteria yang terstandar. Tata cara penentuan lokasi TPA di Indonesia diatur dalam SNI 03-3141-1994. Hal penting yang diatur dalam pedoman ini adalah kesesuaian lokasi TPA dengan RTRW, dimana dinyatakan bahwa lokasi yang digunakan untuk TPA telah ditetapkan dalam RTRW sebagai lokasi TPA. Keterkaitan lokasi TPA dengan wilayah lain diluar batas administrasi sebenarnya telah diatur juga dalam pedoman ini. Namun demikian kriteria ini menggunakan asumsi bahwa lokasi TPA berada dalam wilayah administrasi yang sama dengan daerah pelayanannya. Dalam kenyataannya banyak lokasi TPA yang tidak berada dalam wilayah administrasi yang sama dengan wilayah pelayanannya.

\section{METODA}

Data yang digunakan dalam penelitian ini merupakan data primer dan sekunder. Data primer diperoleh dari wawancara dan pengamatan. Wawancara dilakukan dengan Kepala Desa Taman Rahayu dan Perwakilan Warga setempat. Wawancara terhadap perwakilan warga dihentikan ketika jawaban para responden dapat diprediksi. Responden merupakan perwakilan setiap Rukun Warga (RW) di tiga RW Desa Taman Rahayu yang terkena dampak. Terdapat 13 responden di RW5, 11 responden di RW6, 20 responden di RW7 yang diwawancarai. Data sekunder diperoleh dari berbagai dokumen.

Data-data yang diperoleh dianalisis dengan menggunakan analisis konten dan analisis statistik deskriptif. Tidak dilakukan inferensi untuk data-data yang diperoleh dari wawancara dengan responden karena kriteria sampel random tidak terpenuhi. 
Penyediaan Infrastruktur dan Environmental Justice:

Dampak Keberadaan Tempat Pembuangan Akhir Sampah bagi Masyarakat Sekitar

\section{DAMPAK TPST BANTARGEBANG BAGI MASYARAKAT DESA TAMAN RAHAYU}

\subsection{TPST Bantargebang}

TPST Bantargebang terletak berbatasan dengan Kabupaten Bekasi di Desa Taman Rahayu. Luas Area TPST Bantargebang adalah 110,3 ha, luas efektif TPST adalah $81,91 \%$ dan sisanya $18,09 \%$ untuk prasarana. Lahan TPST merupakan milik Pemerintah Provinsi DKI Jakarta. TPST Bantargebang mulai beroperasi tahun 1989.

TPST Bantargebang saat ini menerapkan metoda sanitary landfill. Proses-proses yang dilakukan di TPST Bantargebang adalah penimbangan, pembongkaran sampah dari truk ke titik buang dengan menggunakan alat berat, pemadatan, penutupan tanah setebal $20-30 \mathrm{~cm}$, tahap terakhir adalah landfill.

TPST Bantargebang dibagi kedalam enam zona pembuangan. Lima zona diperuntukan untuk pembuangan sampah asal DKI Jakarta, dan satu zona diperuntukan untuk pembuangan sampah asal Kota Bekasi. Setiap zona pembuangan dilengkapi dengan pipa-pipa plastik ukuran 10 inchi yang digunakan untuk mengalirkan gas metana. Gas metana dialirkan kedalam power house untuk dibakar. Leachete atau lindi dialirkan kedalam bak penampung yang berada di tengahtengah kawasan. Walaupun pengelolaan sampah di TPST Bantargebang sudah cukup baik saat ini, namun kondisi pengelolaan sampah sebelumnya masih menimbulkan dampak terhadap masyarakat. Sebelumnya, SOP sanitary landfill belum diterapkan dengan baik. Air lindi yang dihasilkan belum tertangani dengan baik. Proses pembongkaran sampah tidak sesuai dengan prosedur yang ditetapkan, dan kurang terawatnya drainase atau saluran air lindi (Winahyu, 2009).

Djatmiko Winahyu, Strategi Pengelolaan Sampah pada Tempat Pembuangan Akhir Bantargebang, Bekasi, Tugas Akhir pada Sekolah Pascasarjana, Institut Pertanian Bogor, 2009

\subsection{Desa Taman Rahayu}

Desa Taman Rahayu merupakan desa di Kabupaten Bekasi yang berbatasan langsung dengan TPST Bantargebang. Desa Taman Rahayu berbatasan dengan Desa Taman Sari di sebelah utara, Kabupaten Bogor di sebelah selatan, Kota Bekasi di sebelah barat, dan Desa Cikarageman di sebelah timur. Desa Taman Rahayu pada tahun 2015 berpenduduk 13.409 jiwa dengan kepadatan $3.735 \mathrm{jiwa} / \mathrm{km}^{2}$. Rata-rata jumlah anggota keluarga adalah 4 orang. Jenis penggunaan lahan yang dominan adalah lahan non pertanian. Luas lahan pertanian hanya sekitar $0,7 \mathrm{~km}^{2}$. Keseluruhan lahan di Desa Taman Rahayu merupakan lahan hak milik. Sebagian besar keluarga merupakan kelompok Sejahtera II. Kelompok keluarga sejahtera II merupakan kelompok keluarga yang tidak memenuhi indikator atau kriteria kebutuhan pengembangan (development needs), yaitu keluarga berupaya meningkatkan pengetahuan agama, penghasilan keluarga ditabung dalam bentuk uang atau barang, kebiasaan keluarga makan bersama paling sedikit seminggu sekali yang dimanfaatkan untuk berkomunikasi, keluarga ikut dalam kegiatan masyarakat di lingkungan tempat tinggal, dan keluarga memperoleh informasi dari surat kabar, majalah, radio, TV, internet. Informasi mengenai Desa Taman Rahayu dapat dilihat pada Tabel 1.

Jumlah rumah tangga di RW 5, RW 6, dan RW 7 Desa Taman Rahayu yang merupakan RW yang terkena dampak adalah $1485 \mathrm{KK}$ atau $42,5 \%$ dari jumlah rumah tangga Desa Taman Rahayu. Jumlah rumah tangga di RW 5 adalah 311, RW 6 adalah 495, dan RW7 adalah 679 (BPS, 2016b). Jumlah KK keseluruhan di RW yang terkena dampak paling besar adalah sebesar $1485 \mathrm{KK}$.

\subsection{Dampak Keberadaan TPST Bantargebang terhadap Masyarakat Desa Taman Rahayu}

\section{Karakteristik dan Persepsi Responden}

Pendidikan terakhir responden menunjukkan nilai yang bervariasi, namun responden di RW 7 menunjukkan tingkat pendidikan yang paling tinggi. Responden pada umumnya telah lama tinggal pada lokasi pada saat ini, umumnya lebih dari 10 tahun. Rumah yang ditempati pada umumnya adalah rumah sendiri. Sumur merupakan sumber air utama yang digunakan untuk MCK, sedangkan untuk memasak dan minum menggunakan air gallon (di RW 6 dan 7) dan sumur (RW5). Masih digunakannnya sumur untuk minum dan memasak di RW5 kemungkinan disebabkan karena tingkat pendidikan, persepsi terhadap kesehatan, dan juga penghasilan yang relatif rendah dibandingkan dengan dua RW lainnya. Sebagian besar penduduk di RW 5 mempunyai persepsi bahwa sumber air cukup bersih, sementara sebagian yang lain menyatakan keruh. Secara umum pengeluaran untuk air berkisar dari $\mathrm{Rp}$ 100.000 hingga Rp 300.000. Penyakit utama yang diderita adalah dermatitis, diare dan ISPA, 
yang merupakan penyakit yang diduga berhubungan dengan pencemaran air dan udara. Kondisi udara dipersepsikan buruk. Biaya berobat berkisar antara $\mathrm{Rp} 100.000$ - Rp 500.000 , dan sebagian besar responden berobat di klinik swasta. Informasi ini dapat memperbaiki informasi dari data Puskesmas, karena tidak semua masyarakat berobat ke Puskesamas. Parameter-parameter fisik, sosial, ekonomi RW 5, RW 6, RW 7 Desa Taman Rahayu ditunjukkan pada Tabel 2.

Tabel 1. Karakteristik Desa Taman Rahayu

\begin{tabular}{lccc}
\hline \multicolumn{1}{c}{ Data } & Nilai & Satuan & Sumber \\
\hline Jumlah Penduduk & 13409 & Jiwa & ${ }^{*}$ \\
\hline Jumlah Rumah Tangga & 3491 & $\mathrm{KK}$ & ${ }^{*}$ \\
\hline Rata-rata Jiwa per Rumah Tangga & 4 & jiwa/KK & ${ }^{*}$ \\
\hline Luas Wilayah & 3.59 & $\mathrm{~km} 2$ & ${ }^{* *}$ \\
\hline Kepadatan Penduduk & 3735 & jiwa/km2 & ${ }^{* *}$ \\
\hline Penggunaan Lahan & & & \\
\hline Pertanian sawah non irigasi & 0.2 & $\mathrm{~km} 2$ & \\
\hline Lahan pertanian non sawah & 0.5 & & \\
\hline Lahan non pertanian & 2.89 & & \\
\hline Kepemilikan Lahan & Hak Milik & & \\
\hline Jumlah Keluarga & & & \\
\hline Pra Sejahtera & 766 & & \\
\hline Sejahtera I & 894 & & \\
\hline Sejahtera II & 1054 & & \\
\hline Sejahtera III & 747 & & \\
\hline Sejahtera III+ & 234 & & \\
\hline
\end{tabular}

Keterangan

* BPS (2016a)

** BPS (2017)

*** Kementan (2017)

**** Wawancara Badang Pemberdayaan Perempuan Keluarga Berencana (2016)

Catatan: terdapat perbedaan antara jumlah keluarga/jumlah rumah tangga berdasarkan data BPS (2016a) dan Badan Pemberdayaan Perempuan Keluarga Berencana (2016)

Tabel 2. Parameter Fisik, Sosial, Ekonomi RW5, RW6, RW7 Desa Taman Rahayu

\begin{tabular}{|c|c|c|c|}
\hline \multirow{2}{*}{ Parameter } & \multicolumn{3}{|c|}{ Nilai Parameter (Modus) } \\
\hline & RW5 & RW6 & RW7 \\
\hline Pendidikan Terakhir & Tidak Bersekolah Formal & SMP & SMA \\
\hline Lama Tinggal & $>10$ thn & $>10$ thn $(100 \%)$ & $>10$ thn $(55 \%)$ \\
\hline $\begin{array}{l}\text { Status Kepemilikan } \\
\text { Rumah }\end{array}$ & Milik Sendiri & Milik Sendiri (100\%) & Milik Sendiri (100\%) \\
\hline Jarak dari TPST & $100-500 \mathrm{~m}$ & $<100 \mathrm{~m}$ & $100-500 \mathrm{~m}(65 \%)$ \\
\hline Sumebr Air MCK & Sumur $(100 \%)$ & Sumur (100\%) & Sumur $(100 \%)$ \\
\hline $\begin{array}{l}\text { Sumber Air untuk } \\
\text { Masak }\end{array}$ & Sumur $(77 \%)$, galon (33\%) & Galon (64\%) & Galon $(60 \%)$ \\
\hline $\begin{array}{l}\text { Sumber Air untuk } \\
\text { Minum }\end{array}$ & Sumur $(77 \%)$, galon (33\%) & Galon (73\%) & Galon (100\%) \\
\hline Pendapatan (Rp) & 2.500 .000 & 2.500 .000 & $2.500 .000-3.500 .000$ \\
\hline Biaya untuk air (Rp) & $100.000-300.000$ & $100.000-300.000$ & $100.000-300.000$ \\
\hline Kondisi Air & Bersih (46\%), Keruh (46\%) & Keruh $(55 \%)$ & Keruh dan Berbau (95\%) \\
\hline Kondisi Udara & Berbau (85\%) & Berbau (100\%) & Berbau (100\%) \\
\hline Kartu Asuransi & Punya $(69 \%)$ & Punya (27\%) & Punya $(70 \%)$ \\
\hline Tempat Berobat & Klinik Swasta & Klinik Swasta (82\%) & Klinik Swasta \\
\hline Penyakit & $\begin{array}{l}\text { Dermatitis }(40 \%) \text {, Diare } \\
(33 \%) \text {, ISPA }(27 \%)\end{array}$ & $\begin{array}{l}\text { Diare }(33 \%) \text {, ISPA }(30 \%) \text {, } \\
\text { Dermatitis }(22 \%)\end{array}$ & $\begin{array}{l}\text { Dermatitis }(38 \%) \text {, Diare } \\
(35 \%) \text {, ISPA }(22 \%)\end{array}$ \\
\hline $\begin{array}{l}\text { Biaya Berobat (Rp) } \\
\text { per kedatangan }\end{array}$ & $100.000-300.000(85 \%)$ & $100.000-500.000(55 \%)$ & $100.000-500.000(60 \%)$ \\
\hline
\end{tabular}


Penyediaan Infrastruktur dan Environmental Justice:

Dampak Keberadaan Tempat Pembuangan Akhir Sampah bagi Masyarakat Sekitar

Sumber: kuesioner dari 13 responden di RW 5, 11 responden di RW 6, 20 responden di $R W 7$

Kualitas air berdasarkan hasil pengujian sampel air penduduk menunjukkan bahwa sebagian besar tidak memenuhi standar kualitas air untuk nitrit, $\mathrm{pH}$, dan coliform. Data yang tersedia hanya mencakup satu RW yang terkena dampak, yaitu RW 6 . Pada RW 6 terdapat 5 sumur yang dijadikan sampel. Terdapat 3 sumur yang tidak memenuhi standar nitrit, dan 3 sumur yang tidak memenuhi standar coliform, dan semua sumur tidak memenuhi standar $\mathrm{pH}$. Nitrit dan coliform berkaitan dengan pencemaran yang kemungkinan disebabkan oleh TPA. Kondisi sumur yang keruh dan berbau terjadi pada semua sampel sumur, tidak hanya pada sumur di RW 6. Data hasil pengujian kualitas air di Desa Taman Rahayu ditunjukkan pada Tabel 3.

Tabel 3 Pengujian Kualitas Air di RW 6 Desa Taman Rahayu

\begin{tabular}{cccc}
\hline \multirow{2}{*}{ Sumur } & \multicolumn{3}{c}{ Parameter } \\
\cline { 2 - 4 } 1 & Nitrit & pH & Coliform \\
\cline { 2 - 4 } & $\mathrm{X}$ & $\mathrm{X}$ & $\mathrm{X}$ \\
\hline 2 & $\mathrm{X}$ & $\mathrm{X}$ & $\mathrm{X}$ \\
\hline 3 & $\mathrm{X}$ & $\mathrm{X}$ & $\sqrt{ }$ \\
\hline 4 & $\sqrt{ }$ & $\mathrm{X}$ & $\sqrt{ }$ \\
\hline 5 & $\sqrt{ }$ & $\mathrm{X}$ & $\mathrm{X}$ \\
\hline
\end{tabular}

Sumber: Puskesmas Setu II, 2015

Keterangan: $X$ tidak memenuhi standar, $\checkmark$ memenuhi standar

Berdasarkan hasil wawancara dengan tokoh masyarakat serta pengamatan terhadap beberapa data, dampak negatif yang dirasakan masyarakat yang dipengaruhi oleh keberadaan TPST Bantargebang adalah kualitas air yang rendah, sehingga masyarakat harus mendapatkan air dari sumber lain. Kualitas air yang rendah juga diperkirakan berhubungan dengan banyaknya kejadian penyakit yang berhubungan dengan air, seperti dermatitis. Selain kualitas air yang berhubungan dengan pencemaran air, pencemaran udara juga merupakan dampak penting yang dirasakan masyarakat. Walaupun belum ada pembuktian hubungan antara kualitas air dan udara dengan berbagai penyakit di Desa Taman Rahayu, namun proporsi penyakit diare, dermatitis, dan ISPA merupakan yang tertinggi.

Berdasarkan hasil observasi dan wawancara dengan responden, TPST Bantargebang masih mengeluarkan bau yang mengurangi kenyamanan. Debu dan sampah-sampah yang tertiup angin juga mengurangi estetika lingkungan. Keberadaan TPST juga telah menurunkan nilai lahan dan bangunan. Beberapa anggota masyarakat berkeinginan pindah dari lokasi tersebut, namun sulit untuk menjual lahan dan properti.

Sejauh ini upaya yang dilakukan masyarakat untuk menanggulangi dampak adalah dengan membeli air untuk konsumsi. Warga yang mampu memilih untuk pindah dan menyewakan rumahnya. Namun proporsi warga yang memilih pindah tidak banyak.

\section{KESIMPULAN DAN REKOMENDASI}

Lokasi TPST Bantargebang berbatasan langsung dengan Desa Taman Rahayu, Kabupaten Bekasi. Walaupun prosesproses di TPST Bantargebang telah diperbaiki saat ini, namun proses yang tidak memenuhi SOP di masa lampau, terutama dalam penanganan lindi, telah menimbulkan dampak terhadap masyarakat Desa Taman Rahayu. Dampak-dampak yang timbul antara lain adalah kualitas air yang buruk, bau, ketidaknyamanan, buruknya estetika lingkungan, dan penurunan nilai lahan dan bangunan.

Terdapat beberapa hal yang direkomendasikan untuk menangani atau mengurangi dampak keberadaan TPST Bantargebang. 
1. Penyediaan air bersih publik atau komunal dengan menggunakan sistem perpipaan. Saat ini wilayah yang terkena dampak belum terlayani air bersih publik, sehingga masyarakat harus membeli air untuk keperluan konsumsi.

2. Penyediaan buffer zone yang membatasi lahan TPST dan pemukiman penduduk. Saat ini belum ada buffer zone sebagai pembatas. Lahan TPST langsung bersinggungan dengan lokasi pemukiman. Keberadaan buffer zone dapat mengurangi bau dan meningkatkan estetika lingkungan. Beberapa jenis tanaman dapat mengurangi bau dan menyerap partikel-partikel pencemar udara. Tanaman ini dapat ditanam pada buffer zone

3. Penanganan dan pengelolaan lindi untuk masa yang akan datang harus dilakukan secara ketat dengan memperhatikan standar yang berlaku.

4. Dari sisi pedoman atau peraturan, perlu adanya kriteria yang menyangkut lokasi TPA yang berbeda antara wilayah pelayanan dan lokasi TPA, juga untuk kasus dimana lokasi TPA berbatasan dengan wilayah administrasi lainnya yang berbeda.

\section{Ucapan Terimakasih}

Terimakasih kepada Bappeda Kabupaten Bekasi yang telah membantu menyediakan data untuk paper ini.

\section{DAFTAR PUSTAKA}

Badan Pemberdayaan Perempuan

Keluarga Berencana. (2016). Laporan

BPS. (2016a). Kabupaten Bekasi dalam Angka

BPS. (2016b). Monografi Desa

BPS. (2017). Kecamatan Setu dalam Angka

Cai, B., Wang, J., Long, Y., Li, W., Liu, J., Ni, Z., Bo, X., Li, D., Wang, J., Chen, X., Gao, Q., Zhang, L. (2015). Evaluating the Impact of Odors from 1955 landfills in China using a Bottom-up Approach. Journal of Environmental Management, Vol.164, p 206-214

Clough, E. (2018). Environmental Justice and Fracking: A Review. Current Opinion in Environmental Science \& Health, Vol.3, p14-18

EPA. (2016). Technical Guidance for Assessing Environmental Justice in Regulatory Analysis

Jenkins, K. (2018). Setting Energy Justice apart from the Crowd: Lesson from Environmental and Climate Justice. Energy Research \& Social Science, Vol.39, p. 117-121

Kapelewska, J., Kotowska, U., Karpinska, J., Astel, A., Zielinski, P., Suchta, J., Algrzym, K. (2019). Water Pollution Indicators and Chemometric Expertise for the Assessment of the Impact of Municipal Solid Waste Landfills on Groundwater Located in their Area. Chemical Engineering Journal, Vol. 359, p.790-800.

Kementan. (2017). Laporan PPL Pertanian Kecamatan Setu

KLHK (2019). Sistem Informasi Pengelolaan Sampah Nasional. www.sipsn.menlhk.go.id (diunduh 6 Februari 2019)

Liu, Y., Lu, W., Wang, H., Gao, X., Huang, Q., (2019). Improved Impact Assessment of Odorous Compounds from Landfills using Monte Carlo Simulation. Science of The Total Environment, Vo. 648, p.805-810

Makarenko, N. dan Budak, O. (2017). Waste Management in Ukraine: Municipal Solid Waste Landfills and their Impact on Rural Areas. Annals of Agrarian Science, Vol 15, p 80-87

McCauley, Darren and Heffron, Raphael (2018). Just Transition: Integrating Climate, Energy and Environmental Justice. Energy Policy Vol. 119, p.1-7

Mitchell, F.M. (2019). Water (in)security and American Indian health: Social and Environmental Justice Implications for Policy, Practice, and Research. Public Health, 17 Januari 2019 (in Press)

Mitchell, G. dan Dorling, D. (2003). An Environmental Justice Analysis of British Air Quality. Environment and Planning A. Vol 35(5), p.909-929

Sanchez-Arias, M., Riojas-Rodriguez, H., Catalan-Vazquez, M., Terrazas-Meraz, 
Penyediaan Infrastruktur dan Environmental Justice:

Dampak Keberadaan Tempat Pembuangan Akhir Sampah bagi Masyarakat

Sekitar

M.A., Rosas, I. Espinosa-Garcia, A.C., Santos-Luna, R., Siebe, C. (2019). Socio-environmental Assessment of a Landfill using a Mixed Study Design: A Case Study from Mexico. Waste Management, Vol.85, p.42-59

Weber, G, Cabras, I., Calaf-Forn, M., PuigVenteso, I., D'Alisa Giacomo. Promoting Waste Degrowth and Environmental
Justice at a Local Level: The Case of Unit-Pricing Schemes in Spain. Ecological Economics, Vol.156, p.306317

Winahyu, D., 2009. Strategi Pengelolaan Sampah pada Tempat Pembuangan Akhir Bantargebang, Bekasi. Tugas Akhir pada Sekolah Pascasarjana. Institut Pertanian Bogor 